\title{
REVIEW: Sounds of Then, Sounds of Now - Popular Music in Australia, Hobart
}

\author{
Transforming Cultures eJournal, \\ Vol. 4 No 1 April 2009 \\ http://epress.lib.uts.edu.au/journals/TfC
}

Sounds of Then, Sounds of Now - Popular Music in Australia, Hobart, edited by Shane Homan and Tony Mitchell, ACYS, 2008. 295 pp. ISBN 878-1-875236-60-2

\section{Theo van Leeuwen}

Homan and Mitchell's book is subtitled 'Popular Music in Australia' and appears in a time when Australian popular music enjoys increasing commercial success, But it is not an unqualified celebration. On the contrary, in their introduction Homan and Mitchell start off on a critical note. Australian popular music, they say, "is generally associated with crowded, sweaty pubs, raucous singalongs and drunken Anglo-Australian masculinity" and is not inclusive of Aboriginal music, of women, of any perspectives other than mainstream sensibilities and of any genre other than rock.

In his chapter on 'Oz Rock', Homan qualifies this by writing with some feeling about this music's focus on 'earthy intense live performances', an aspect of the music which in one striking quote from the 2003 press kit for a Midnight Oil tribute band is linked to 'our geography and climate' and to all the essentials of Australian mythology:

...The world has witnessed this tenacity, endurance and commitment from Australian athletes, diplomats and everyday people. No better example could be cited than our very own heroic Anzacs...

And although Homan chronicles a gradual decline of this dominant strand of Australian popular music, he also shows that it continues to be a 'marker of local distinction in the global market' and a 'standard accessory in the pursuit of stardom'.

Following this first chapter, the book leaves popular music well alone, and in a move characteristic of much of the best Australian intellectual and creative work, focuses defiantly on much more unpopular forms of music - experimental musics that draw 
audiences of 30 or 40 devoted connoisseurs in hard-to-find venues; jazz and other forms of improvised music which, despite the brilliance and commitment of its young musicians, continue to lead a precarious existence, even in a city of 4 million such as Sydney; and much more. This is what the book seems to celebrate most - not stardom and commercial success, but forms of local music which, despite the indifference of mainstream culture, keep going and keep going well, because of the singular commitment of its proponents.

Next on the agenda is subversive music - music that goes against the grain, again for the most part followed only by dedicated audiences, and well under the radar of television exposure and media fame. And the music of minorities, as in Karl Neuenfeldt's lovely chapter on the contemporary music of Torres Strait Islanders where you can almost imagine yourself sitting in people's living rooms, or in a local pub, listening to the reminiscing and the singing. And, towards the end of the book, Tony Mitchell's chapter on Hip Hop, where some much more recent developments crop up, placing Hip Hop at the other end of the spectrum from Oz Rock - as embracing multiethnicity and multi-lingualism rather than Anglo-Australian dominance, and educational and spiritual causes such as literacy and religion rather than alcohol and youthful rebellion, and as having a strong Aboriginal take up rather than the exclusion of Aboriginal music signaled in the Introduction.

The final chapter, by Alison Huber, returns to popular music, to the Top 40, in fact. But in contrast to the other chapters, this chapter treats its subject, not with affection, but from a distance, as an institution, a phenomenon, and without zooming in to specific singers and groups. The focus here is not so much on mainstream music as on the 'material circumstances that enable songs to appear to us as culturally dominant forms of popular music'. Sounds of Then, Sounds of Now therefore starts and ends with dominant music, but only as a frame within which the larger part of the book celebrates the creative spirit of Australian musicians who, against many odds, hang on to their values, continue to experiment, and survive. As an intellectual enterprise, this book can itself be seen as part of that same spirit - local, defiant, sticking to its values.

It is also a very good read. Homan and Mitchell have put together a cast of writers who are passionate about their subjects, thoughtful and theoretically interesting, and 
immensely knowledgeable, not only about the histories and personalities of the various kinds of music they write about, but also about the music itself, which is by no means always the case in writings about popular music. Sounds of Then, Sounds of Now is perhaps also one of the very few 300-page edited academic books I have ever read with pleasure in one sitting. It deserves to be read widely by anyone with an interest in Australian music, and in an inclusive view of Australian popular culture. 